\title{
Romantic Hybridity and Historical Poetics: Lyricization and the Elegiac
}

\author{
Tim Fulford \\ De Montfort University
}

"Historical Poetics" as an agenda of the eponymous research group of which Virginia Jackson, Meredith Martin, and Meredith McGill, among others, are members has meant several things. In Yopie Prins's definition, it comprises the study of the way poems have been "read through the generic conventions that make up the history of reading poetry." "From the external perspective of Simon Jarvis, it entails the recognition that "the (historical) truth content of works of art is to be sought precisely in their technical organization, which, far from being a transhistorical frame for the work of art, is instead its most intimately historical aspect." ${ }^{2}$ Few would object to the adoption of either of these statements as watchwords for a critical methodology that aims to examine form, prosody and genre as they operate in particular poems in particular times and places - a methodology that implies a historicized account of how poetry was understood when it was first produced and consumed. More controversial is the particular historicized account produced by some of the Historical Poetics group, notably Virginia Jackson. ${ }^{3}$ This account suggests that the predominant trend in literary historiography, from the eighteenth century to today, has been self-fulfilling. Critics and commentators, it is suggested, have so strongly argued that poetic history is a teleological progress of ever-increasing lyricization that it has become so: readers and even writers have been gradually conditioned, by reviewers, critics, editors and educators, to value poetry as lyric: i.e. the melodious, song-like revelation of intense subjective passion felt by an inferred speaker or thinker. J. S. Mill's declaration that true poetry is "feeling confessing itself to itself in moments of solitude," ${ }^{\prime 4}$ is taken to be exemplary of the trend: by such pronouncements writers and readers, it is argued, were taught to produce and consume poetry as lyric, that is, as thought which they overheard as if speech: they were positioned as privileged listeners to the narrator's

1 Prins, "What is Historical Poetics?", MLQ, 77.1 (2016): 13-40 (15).

2 Jarvis, "What Is Historical Poetics?" Theory Aside, ed. Jason Potts ar el Stout (Durham,

NC: Duke University Press, 2014), 97-116 (100-1).

3 See Jackson, "Lyric," The Princeton Encyclopedia of Poetry and Poetics $4 \mathrm{ln}$ eu (Princeton: Princeton University Press, 2012) 826-34 and the "General Introduction" to The Lyric Theory Reader: A Critical Anthology, ed. Jackson and Yopie Prins, (Baltimore, MD: Johns Hopkins University Press, 2014).

4 "Thoughts on Poetry and its Varieties," The Monthly Repository, NS 7 (1833): 60-70. 
mind, as if transcending the materiality of the print or manuscript medium in which they encountered the poem. ${ }^{5}$

In arguing thus, the Historical Poetics group sought to challenge influential aestheticians, past and present, who assert that lyric is a transhistorical mode. The group conceives lyric as begotten, not eternal, and begotten by the professionalizing discipline of literary criticism more than by poets. The group's practice, it follows, is founded on a Marxist demystification of the aesthetic as the production of a particular, specialized, class of knowledge-producers. The lyric as ideology.

Historical demystification is, though a powerful strategy, not a difficult one to adopt: it benefits from hindsight. Its inherent weakness is a tendency towards overstatement: the thing to be demystified has to have a lot of power attributed to it to make the process worthwhile (the role of purifiers is justified by the pervasiveness of the corruption they are to clean up). And this tendency is evident in the account of lyricization-which sometimes assumes the existence of the category of the lyrical that it is its purpose to prove (as when, in Jackson's article on Lyric in The Princeton Encyclopedia, Longinus is recruited as evidence of the development of "organic poetic form" and "an ideal of personal lyricism" although he never uses these twentieth-century terms ${ }^{6}$ ). In consequence, Jackson's argument sometimes mirrors the arguments it ostensibly challenges: whereas critics such as M. H. Abrams assembled critical pronouncements from the past to demonstrate that lyric has always existed - a transhistorical category of passionate poetry that was interpreted differently at different times-Jackson uses similar (indeed, sometimes the nama) critical pronouncements to show that it is a historical construction that cumul gathered power because of the work of critics from the eighteenth century onwaras. Different conclusions are drawn from the evidence, but the evidence is not contested. The result is reification rather than clearing of the field: demystification makes lyricization loom large as the poetic history of (at least) the last 250 years.

When, in 1965, Abrams wrote of the "Greater Romantic Lyric" he was proposing a category, rather than confirming one that he thought previous critics had already set out. ${ }^{8}$ In doing so, he was taking up the mantle of the New Critics, developing a

5 See Celeste Langan, "Understanding Media in 1805: Audiovisual Hallucination in The Lay of the Last Minstrel," SiR, 40 (2001): 49-70, Virginia Ja-non "Who R-d D-etry?" "Lyric," Special cluster, PMLA, 123 (2008): 183, and Dickinson's Mis heory of ading (Princeton: Princeton University Press, 2005). Behind their argu tand the f Mary Poovey, "The Model System of Contemporary Literary Criticism," Critical Inquiry, 27 (2001): 408-38, Clifford Siskin, The Historicity of Romantic Discourse (Oxford: Oxford University Press, 1988), 3-63, and Anthony Easthope, who suggested that Wordsworth strove in "Tintern Abbey" to produce an illusion of a normative meditative voice, initiating a nineteenth-century poetic in which poet and reader are divorced from historical contingency, mystifying the act of reading as timeless telepathy, Easthope, Poetry as Discourse (London and New York: Routledge, 1983), 125-33.

6 "Lyric," in The Princeton Encyclopedia of Poetry and Poetics.

7 Jackson's position is somewhat modified in her "American Romanticism, Again," Studies in Romanticism, 55 (2016): 319-46.

8 "Structure and Style in the Greater Romantic Lyric," in From Sensibility to Romanticism: Essays 
post-Modernist tendency to value poems as short, intense, verbal icons (on which, see Kermode, Romantic Image). ${ }^{9}$ He was recognizing lyricism, as various critics had at different times in different texts, rather than self-consciously developing a trajectory of lyricization that began before the romantic period. Viewing his work as the culmination of a long term process, Jackson makes him the inheritor not just of Wimsatt and Brooks but also of Longinus, Dennis and Goethe. Back-projected in this way, lyricization becomes a critical construction of the deep past, rather than of mid-twentieth century professional literary criticism.It appears to have not just critical authority, but to have been a norm under which poets, historically, had to work. Constituting the poetic revelation of passionate subjectivity, the "lyric," it is implied, had become a mode for which poets reached whatever the traditional genre they were writing in. Thus, it gradually became a super-genre, and the traditional genres receded, some of them dying out.

Backdating the lyricization process gives it great power, but risks corralling poetic history and limiting historical poetics as a methodology. Is the practitioner of Historical Poetics to find lyricization where and whenever she looks? Are other developments to be reduced to tributaries, or to minor currents outside the main stream? The most-recent Princeton Encyclopedia entry on Lyric tends towards Whig history: such is its rhetorical organization that counter-evidence to its developmental narrative is acknowledged only to be parked. What does not fit is reduced a r or two in the smooth and flowing line drawn from medieval to modern wrimys: thus, the history of lyric becomes a lyricization of history.

As if in tacit acknowledgement of the problem, a number of critics who identify themselves as being engaged upon Historical Poetics effectively set aside the grand narrative of lyricization, other than as a somewhat gestural figure of critical practices that they oppose. The work of Yopie Prins and Meredith McGill, for instance, takes its impetus not primarily from critical pronouncements, but from the various working practices of poets as revealed by their engagement with, on one hand, historical poetic genres and, on the other, the print culture — not least the book market—of their times. ${ }^{10}$

Romanticism, however, has not been their principal concern, and it remains neglected in their accounts. This present collection of essays addresses this neglect, showing how it must be construed as rather more than, and rather different from, its role in The Princeton Encyclopedia, where it is merely a minor bump on the road to lyricization. Indeed, given romanticism's continuing influence on Victorian literature, the very existence of that road-at least as the main road of poetic history, can be questioned.

Presented to Frederick A. Pottle, ed. Frederick W. Hilles and Harold Bloom (New York: Oxford University Press, 1965), 527-60.

9 Frank Kermode, Romantic Image (London: Routledge and Kegan Paul, 1957).

10 Yopie Prins, Victorian Sappho (Princeton: Princeton University Press, 1999); Meredith L. McGill, American Literature and the Culture of Reprinting, 1834-1853 (Philadelphia: University of Pennsylvania Press, 2003). 
Hybridity was the romantic mode of innovation. Romantic poets did not operate under a dominant poetics of lyricization-nor primarily with "lyrics"-but with "lyrical"-lyrical as an adjective qualifying the name of a traditional genre rather than as an ideal category or quality ("the lyrical"). They used "lyrical" in a book title-as Mary Robinson did in her Lyrical Tales-to advertise to prospective purchasers that they were mixing two popular kinds of poem-narrative genres (tale and ballad) — and melodious effusions (songs). The latter, popularized by their hero Burns, were patterned for vocal performance (to aid the singer and the listener, they employed rhymes, refrains, contractions of words and elongations of syllables across the meter). They were expected to be passionate and, at least sometimes, to seem the spontaneous emotional outpouring of the singer. But the point was not that these song-like aspects were to subsume the narrative aspects-that "lyrical" should dominate ballad and that verse should aspire purely to become a melodious overflow of feeling. The tension between the two was the point, as the book titles declared: the poets aimed to revive ossified genres by letting one play against another, as motion depends on the play of a wheel on its axle. Lyrical ballads and lyrical tales, for instance, aimed, unlike the old ballads revived by Percy, Ritson and Scott, to make lower-class genres narrate the lives of contemporary rustics-their actions as much as their feelings. This concern to narrate the deeds, as well as the subjectivity, of classes normally excluded from polite literature was fundamental to romantic poetry's hybridization of genres. The result, the democratization of narrative, with an accompanying transfer not just of feeling but also of heroic action to new classes, was massively influential on literary history, whether on the Victorian novel (the Brontes; Eliot; Hardy), the Chartist and socialist songs of the labour movement (Elliott; Davenport), or the rural tales of Hardy, Barnes and Thomas. It is, however, significantly absent from Jackson's Princeton Encyclopedia account: her historicization of the model of lyric set out by mid-twentieth century critics effectively turns poetic history into a teleology moving towards the critical distillation of "the lyrical" and "lyric" as an ideal mode of expressing subjective feeling, and this impedes her recognition of both the nature of the romantic revolution and the power of its effects. It also downplays lyrics' importance as texts for singing-their prime function not just in the sixteenth, late eighteenth and nineteenth centuries but also to this day, as the merest glance at Youtube and Spotify reveals. The effect of this is to strip the literary lyric of the social and communal elements that are built-in to its function as a text to be sung, or recited, in company. The result is a reinforcement of a critical division between elite literary culture and popular culture that is unhealthy for both.

Romantic hybridity was not a mere preparation for the triumph of lyric, and its affiliation to the narrative genres of the common people was not a residual effect that would drop away. Nor was it solely predicated on hybridizing the lyrical with other genres, forms and modes. Romanticism commonly hybridized other genres and modes as well as the lyrical. In advertising their poems as Lyrical Ballads and Lyrical Tales, Wordsworth, Coleridge and Robinson were hoping to benefit from the 
popularity of Charlotte Smith's hybrid volumes of Elegiac Sonnets. Titles advertising affiliation to more than one genre were, as Stuart Curran points out, ${ }^{11}$ a hallmark of the new poetic movement that began in the 1790s. To name but a few, Coleridge called poems "Religious Musings," "A Poet's Reverie," "A Vision in a Dream"; Byron termed "The Giaour" "A Fragment of a Turkish Tale"; Shelley advertised Hellas, a Lyrical Drama and Moore "An Oriental Romance."

It was understood at the time that the mixing of generic elements heralded by such titles was an attack on the traditional equation of a smooth, flowing style with the passionate speech or thought of an implied speaker. In an influential review of Southey's Thalaba the Destroyer, Francis Jeffrey identified this attack as an attempt to decouple poetry from its traditional association with the values, taste and speech of the upper classes. He singled out Southey's formal and prosodic variety, as well as his mixing of the "low" diction found in ballads with the "high" form of epic, as the modus operandi of a Jacobin poetics that was also evident in Lyrical Ballads:

the singular structure of the versification, which is a jumble of all the measures that are known in English poetry, (and a few more), with rhyme, and without any sort of regularity in their arrangement Every combination of different measures is apt to perplex and disturb the reader who is not familiar with it; and we are never reconciled to a stanza of a new structure, till we have accustomed our ear to it by two or three repetitions. This is the case, even where we have the assistance of rhyme to direct us in our search after regularity, and where the definite form and appearance of a stanza assures us that regularity is to be found. Where both of these are wanting, it may be imagined that our condition will be still more deplorable; and a compassionate author might even excuse us, if we were unable to distinguish this kind of verse from prose. ${ }^{12}$

Southey's long poems seemed like lyrics - they were a mixture of sapphics, dactylics, and various stanza forms derived from classical and Elizabethan short poems. But the mixture of so many forms did not allow readers to settle, preventing them from hearing themselves think: they could not identify in the narration the voice of an implied speaker who shared their aesthetic norms and social values-an effect compounded by the fact that the hero was not, as was to be expected in an epic, a Christian knight, classical warrior or biblical character but a Muslim peasant. Southey repeated these alienating effects in his 1811 epic/romance The Curse of Kehama, asking readers, if they were to follow the plot, to give credence to Hindu

11 Curran, Poetic Form and British Romanticism (Oxford and New York: Oxford University Press, 1986), xi.

12 Review of Thalaba, Edinburgh Review, 1 (1802): 63-83 (63-4). 
beliefs_-although most viewed those beliefs as pagan and superstitious. Formally, the poem was a deconstruction of what Jackson calls the lyrical. Southey had redrafted it in manuscript so as to introduce rhyme, in order that a song-like harmony might offer readers a recognizable aesthetic order to follow. ${ }^{13}$ But he repeatedly disturbed this lyricism before it could soothe readers into familiarity, as Jeffrey astutely remarked in the Edinburgh Review: "instead of the firm march of the Iambic and Trochaic measures, for which alone our language seems to be adapted, we have (besides the poor pedantry of Sapphics and Dactylics) a great variety of tottering and slovenly measures, that were either never introduced into English poetry, or have been long discarded from it." 14 Southey, Jeffrey asserted, spoilt his "tenderness of heart" by the "perversity of his manifold affectations" and "wilful deformities" (452, 434). The problem was formal defamiliarization: forty years before Browning, and over a century before Brecht and Jakobson, Southey's jarring meters and irregular stanzas drew attention to the medium, rather than to the passions of the presumed speaker. They took the reader "behind the scenes ... to catch a peep of the operose and toilsome machinery by which the effect is produced" and thus "perplex[ed]" him "with a perpetual feeling of uncertainty and disappointment" (452). In Jackson's terms, Southey offended against lyric norms: his irregularity of form, prosody and content made poetry's purpose not the crystallization of a normative speaker's emotion but aesthetic disturbance and social innovation.

Despite their disturbing effects, and notwithstanding Jeffrey's opposition, Southey's poems were not ignored in their own time because not lyrical enough. On the contrary, their influence on such generically hybrid works as Alastor, The Revolt of Islam, Lalla Rookh, The Lady of the Lake, The Bride of Abydos, Jane Eyre, and Corn Law Rhymes has been amply demonstrated. ${ }^{15}$ They helped found a nineteenth-century tradition of labouring-class, radical poetry and prose in which, as Anne K. Janowitz has shown, the lyrical elements of verse were used to generate communal solidarity among a social group for political purposes, rather than to invite a solitary reader's silent participation in the thought-process of a solitary implied speaker. ${ }^{16}$ If, however, lyricization was not binding on these writers in their lifetimes it was, as Poovey, Easthope and Jackson agree, ${ }^{17}$ under its aegis that in the twentieth century they

13 See his letters to Grosvenor Charles Bedford, 12 May 1805 and to Walter Savage Landor, 20 May 1808: letters 1066 and 1459 of The Collected Letters of Robert Southey, Part Three, ed. Tim Fulford and Carol Bolton. https://www.rc.umd.edu/editions/southey_letters.

14 Review of The Curse of Kehama, Edinburgh Review, 17 (1811): 429-65 (453).

15 See the introduction to Thalaba the Destroyer, vol. 3 of Robert Southey: Poetical Works 1799-1810, gen. ed. Lynda Pratt (London: Pickering and Chatto, 2004); Nigel Leask, British Romantic Writers and the East: Anxieties of Empire (Cambridge: Cambridge University Press, 1992); Denis Low, The Literary Protégées of the Lake Poets (Aldershot: Ashgate, 2008); W. A. Speck, Robert Southey: Entire Man of Letters (New Haven, CT and London: Yale University Press, 2006), Ernest Bernhardt-Kabisch, Robert Southey (Boston: Twayne, 1977).

16 Janowitz, Lyric and Labour in the Romantic Tradition (Cambridge: Cambridge University Press, 1998).

17 See note 5 above. 
were omitted from the canon of poems thought by university professors to be worth teaching. They were insufficiently individualized, too committed to their historical context, too variable, not lyricized enough. Thus lyricization did cause certain types of poem to be ruled ultra vires, but this happened much later than The Princeton Encyclopedia implies.

Wordsworth's post-1800 poems (his shorter poems at least) met a different reception from Southey's. Canonized from the mid-nineteenth century onwards as revelations of the poet's feeling, on the face of it they fit the bill of lyricization as Jackson describes it. Largely eschewing metrical and stanzaic irregularity, they use the motifs of song and endorse Johnson's view that lyric wanders "without restraint from one scene of imagery to another" and Schlegel's that it is the subjective form of representation (Rambler 158, 21 September 1751; Einschränkung der schönen Künste aufeinen einzigen Grundsatz 1751: both quoted in The Princeton Encyclopedia entry on

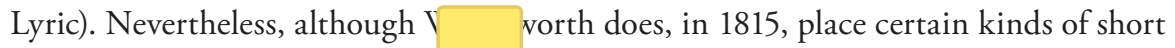
poems in a "lyrical" category of $s$, this is for traditional reasons concerning their material performance: they required musical accompaniment "for the production of their full effect." ${ }^{18}$ He neither associates them with the revelation of the poet's inward thought-process nor even calls them lyrics or lyrical hybrids. Instead, he chooses names such as Evening Voluntaries, Elegiac Musings, and Elegiac Stanzas. In what follows I investigate one of these elegiac hybrids as such, rather than as a lyric that dare not speak its name. My purpose is to sketch out a historical poetics able to consider a romantic-era poem in terms of the poet's own choosing, although it displays many of the motifs and characteristics that Jackson attributes to the process of lyricization. In this I take a cue from Jarvis's emphasis on technique as a way of thinking or arguing through verse and Prins's interest in "the repeated readings that compose the poem's reception, each an act of recognition." ${ }^{19}$ My investigation conceives Wordsworth as developing particular techniques for commemorating the dead from a number of past poems employing stanza forms that, like the anglicized Pindaric Ode, hinged on the interweaving of longer and shorter lines. Adapting these techniques for his elegiac purpose, he effectively elegized the poems he adapted them from, thus retrofitting a genre even as he modified it.

Elegy came down to Wordsworth both as a genre for particular occasions and as a reflective mood. ${ }^{20}$ In classical times elegy ("mournful song") was associated with a particular stanza form, used for first-person poetry, addressing others on particular occasions. It was not simply a poetry of lament, and its variety licensed English

18 Meaning poems for which, "for the production of their full effect, an accompaniment of music is indispensable." In the Preface to Poems ... by … Wordsworth, 2 vols, vol. 1 (London, 1815), xii.

19 Prins, "What is Historical Poetics?" 15.

20 On the history of elegy, see Peter M. Sa__._._glish Elegy: Readings in the Genre from Spenser to Yeats (Baltimore: Johns Hopkins University Press, 1985); Dennis Kay, Melodious Tears. The English Funeral Elegy from Spenser to Milton (Oxford: Clarendon Press, 1990); David W. Shaw, Elegy and Paradox: Testing the Conventions (Baltimore: Johns Hopkins University Press 1994). 
poets such as Drayton and Donne to write epistolary elegies that had nothing to do with death. Nevertheless, Theocritus's idylls, supposedly voiced by a shepherd lamenting loss, became the main source of a central English tradition of pastoral elegy mourning death pioneered by Spenser ("Astrophel") and Milton ("Lycidas"). Donne's "Funeral Elegy," meanwhile, eschewed the pastoral: the poet spoke directly and argumentatively at the graveside. In the eighteenth century Gray used elements of both pastoral and funeral tradition in "Elegy in a Country Churchyard"; Shenstone's pastorals, meanwhile, turned the elegiac away from mourning: elegies, he declared, depended on "a tender and querulous idea" used to "throw a melancholy stole over pretty different objects." ${ }^{21}$ Charlotte Smith also moved the melancholy mood away from the graveside; her elegiac sonnets dramatized lament as a condition of being, a song of self, rather than a response to an occasion. Coleridge was naturalizing this historical development when he declared that

Elegy is a form of poetry natural to the reflective mind. It may treat of any subject, but it must treat of no subject for itself; but always and exclusively with reference to the poet. As he will feel regret for the Past or Desire for the Future, so Sorrow and Love became the principal themes of Elegy. Elegy presents every thing as lost and gone or absent and future. ${ }^{22}$

Despite Coleridge's naturalization, elegy was not simply given but made and remade. When it did respond to a death-as Wordsworth's elegiac poems did-it was forged from a historical tension bearing upon the poet as s/he took up the task that the genre enjoins: on the one hand s/he was motivated by an understanding of what that task had meant historically and what it enjoined for posterity (what the genre as it had been practiced in the past aimed towards) and on the other hand-although this is not in practice entirely separate-s/he was affected by an engagement with the historical circumstances of the dead person's life. The understanding of the task shifted over time: different societies expected different things of the poet; elegy was construed differently; thus, the negotiation between the task, as understood, and the engagement with the life of the deceased (itself an historical variable) changed. In this process, the relationship between elegiac form and voice was reshaped. This reshaping was not a matter of inevitable or linear progress: Wordsworth, for instance, chose, in certain defined circumstances, to hybridize the funerary elegy as he understood it with the modus operandi of seventeenth century "metaphysical" poems.

21 On Shenstone, and the elegiac as a tradition of tender, impassioned and even erotic verse, dating in English verse from Drayton, see David Kennedy, Elegy (London: Routledge, 2007), 3-4 (where Shenstone's remarks are quoted).

22 A remark made on 23 October 1833. The Table Talk of S. T. Coleridge, ed. Carl Woodring, 2 vols (Princeton: Princeton University Press, 1990), I: 444-5. 
The defined circumstances were to do with gender: Wordsworth's poems on dead women were far more likely to update the methods of Marvell and Jonson than were his poems on dead men. These elegies for women exhibit many of the motifs attributed to the lyric, yet resist others. They do not necessarily "treat of no subject for itself; but always and exclusively with reference to the poet." They are less like Smith's practice and Coleridge's theory than belief in historical progress towards lyricization of genres would lead us to expect. A case in point is the poem Wordsworth called "Elegiac Stanzas," written in 1824/25 for his friend and patron Sir George Beaumont on the death of Beaumont's sister-in-law, Frances Fermor.

O for a dirge! But why complain?

Ask rather a triumphal strain

When Fermor's race is run;

A garland of immortal boughs

To twine around the Christian's brows,

Whose glorious work is done.

We pay a high and holy debt;

No tears of passionate regret

Shall stain this votive lay;

Ill-worthy, Beaumont! were the grief

That flings itself on wild relief

When Saints have passed away.

Sad doom, at Sorrow's shrine to kneel,

For ever covetous to feel,

And impotent to bear!

Such once was hers - to think and think

On severed love, and only sink

From anguish to despair!

But nature to its inmost part

Had Faith refined; and to her heart

A peaceful cradle given:

Calm as the dew-drop's, free to rest

Within a breeze-fanned rose's breast

Till it exhales to Heaven.

Was ever Spirit that could bend

So graciously? - that could descend,

Another's need to suit,

So promptly from her lofty throne? - 
In works of love, in these alone,

How restless, how minute!

Pale was her hue; yet mortal cheek

Ne'er kindled with a livelier streak

When aught had suffered wrong, -

When aught that breathes had felt a wound;

Such look the Oppressor might confound,

However proud and strong.

But hushed be every thought that springs

From out the bitterness of things;

Her quiet is secure;

No thorns can pierce her tender feet,

Whose life was, like the violet sweet,

As climbing jasmine, pure; -

As snowdrop on an infant's grave,

Or lily heaving with the wave

That feeds it and defends;

As Vesper, ere the star hath kissed

The mountain top, or breathed the mist

That from the vale ascends.

Thou takest not away, O Death!

Thou strikest - and absence perisheth,

Indifference is no more;

The future brightens on our sight;

For on the past hath fallen a light

That tempts us to adore. ${ }^{23}$

This highly-compressed votive elegy eschews the self-reflection that Gray, Smith and Coleridge had made a recent trend, presenting instead a series of concise "tail-rhyme" stanzas, each dividing into two units of three lines (a couplet followed by a shorter trimeter line), presenting Fermor's life as a number of distinct facets. Here, form serves towards emblematization, as does a skein of imagery through which the dead woman is "refined," verse by verse, from the material context of the funeral into a state of spiritual suspension. This mode of proceeding hybridizes the funeral elegy 
by adapting the argument-by-metaphor of Jonson's "Celebration of Charis" 24 and especially of Marvell's “On a Drop of Dew," wherein the dew-drop's various states indicate the soul's graduated return to the heavens. Wordsworth liked Marvell's poem enough to select it for the anthology he presented in 1819 to Lady Mary Lowther, ${ }^{25}$ and he adapted its formal methods as well as its imagery-his interweaving of shorter trimeter lines echoes Marvell's use of short lines to break the flowing verse sentence into distinct sections:

See how the orient dew,

Shed from the bosom of the morn

Into the blowing roses,

Yet careless of its mansion new,

For the clear region where 'twas born

Round in itself incloses:

And in its little globe's extent,

Frames as it can its native element.

How it the purple flow'r does slight,

Scarce touching where it lies,

But gazing back upon the skies,

Shines with a mournful light,

Like its own tear,

Because so long divided from the sphere.

Restless it rolls and unsecure,

Trembling lest it grow impure,

Till the warm sun pity its pain,

And to the skies exhale it back again. (lines $1-18)^{26}$

Beyond Marvell, a tradition stretching from Shakespeare and Jonson forwards to Christopher Smart's "A Song to David" is invoked in the transforming images that follow-dew, violet, jasmine, snowdrop, lily, vesper. Thus Smart:

Sweet is the dew that falls betimes,

And drops upon the leafy limes;

Sweet Hermon's fragrant air:

Sweet is the lily's silver bell,

24 On Wordsworth's adaptation of Jonson's poems, see Ann Barton, “The Road from Penshurst:

Wordsworth, Ben Jonson and Coleridge in 1802," Essays in Criticism, 38 (1987): 209-33.

25 Poems and Extracts Chosen by William Wordsworth for an Album Presented to Lady Mary Lowther,

Christmas, 1819 (London: Henry Frowde, 1905), 66-7.

26 Marvell, The Complete Poems, ed. Elizabeth Story Donno (Harmondsworth: Penguin, 1976), 102. 
And sweet the wakeful tapers smell

That watch for early pray'r.

Sweet the young nurse with love intense,

Which smiles o'er sleeping innocence;

Sweet when the lost arrive:

Sweet the musician's ardour beats,

While his vague mind's in quest of sweets,

The choicest flow'rs to hive.

Sweeter in all the strains of love,

The language of thy turtle dove,

Pair'd to thy swelling chord;

Sweeter with ev'ry grace endu'd,

The glory of thy gratitude,

Respir'd unto the Lord. (lines 427-44) ${ }^{27}$

Though the images are all commonplace in literary songs, some had a particular history for Wordsworth. "Vesper," the evening star, echoes Wordsworth's own autumnal poem "September 1819," written in the same six-line stanza as the elegy for Fermor, in which the star explicitly analogizes evening prayer:

This, this is holy; - while I hear

These vespers of another year,

This hymn of thanks and praise,

My spirit seems to mount above

The anxieties of human love,

And earth's precarious days. (lines 19-24) 28

Collectively, the 1824 images suggest the dependence of one thing upon its interaction with others, but render the interactions progressively less material. Fermor's life is buoyed on earth (snowdrop), on water (lily) and finally on air-or space (star). Thus spiritualized, it becomes more and more remote from the touch of the world. It is present as a recessed evening star that will, but has yet to, touch the emanations of earth. This withdrawal-but not removal-prepares the way for an extraordinary final stanza:

27 The Poetical Works of Christopher Smart, II, Religious $763-1771$, ed. Marcus Walsh and Karina Williamson (Oxford: Clarendon Press, 1983), 100??-128??. [AQ4]

28 Wordsworth, The River Duddon, a Series of Sonnets: Vaudracour and Julia: and Other Poems. To which is annexed, a topographical description of the country of the Lakes, in the North of England (London, 1820), 187-8. 


\section{Thou takest not away, O Death! \\ Thou strikest - and absence perisheth, \\ Indifference is no more; \\ The future brightens on our sight; \\ For on the past hath fallen a light \\ That tempts us to adore.}

The simplicity of the grammatical structures, the short lines, neatness of rhyme and generality of the metaphors suggest a hymn. But this is deceptive: the simplicity carries a highly unorthodox and compressed argument, and it is this that makes the stanza so striking-and proleptic of Emily Dickinson's poetic methods. How does death's striking make absence perish? Normally it is thought to create absence, not destroy it. Wordsworth offers no gloss, even though the following lines cannot be thoroughly fathomed without understanding the paradox. The reader is forced to think through the connection, rather than treat the reference to the brighter future and illuminated past as bland images of pious assurance. And the connection seems to be that death definitively distils the deceased as the spiritual presence of which her star-like life gave anticipatory knowledge. Death's act of re- and de-finement-a sort of refinition-also illuminates the past since by terminating life, it casts the light of finality upon it, holding it up, complete. Fermor's life, arrested, can now be seen retrospectively as a preparation for heaven-and this inspires the viewer to regard heaven as a nearer, brighter prospect for everyone. By the end, it transpires, what might have been expected to be a poem of lament and mourning has become one that aims to suggest transcendence through formal control.

What makes the poem remarkable is its extreme economy of means, creating a crystalline clarity in which phrases and images that would in other hands be clichés are both sharply focused and put to the service of a novel perception, bringing the reader first gradually and then abruptly to a new view of life and death. All this is achieved not by dint of emotional reflection on a complex relationship with the elegy's subject, Fermor, but by a deployment of the motifs and forms of Marvell and Smart. But "On a Drop of Dew" and "A Song to David" were not formally elegies; nor did they reveal the reflective subjectivity of the poet: Marvell and Smart were not elegiac in Coleridge's sense. Wordsworth turned them in an elegiac direction even as he modified the elegy by crossing it with what becomes, when retrospectively focused by his borrowings, a previously neglected line of poets. In Johnson's terminology, this line was a "metaphysical" tradition; in Wordsworth's it was a poetry of "imagination." 29

29 Johnson coined the term in his "Life" of Cowley. See The Lives of the Most Eminent English Poets; with Critical Observations on Their Works, 2 vols, vol. 1 (London, 1810), 1-50 (13). Worc classified his verse under the heading "Poems of Imagination" in his first collected works, Poen William Wordsworth, 2 vols (London, 1815). He helped construct a tradition dating from seventeenth century verse by anthologizing neglected poems in Poems and Extracts Chosen by William Wordsworth. 
Wordsworth had used the tail-rhyme stanza several times before 1824 in poems that he classified as being of the imaginative kind. In each case, he used the form as he sought to commemorate lost nature-girls. " ${ }^{30}$ "Ruth" used the form; so did "Louisa." 31

And she hath smiles to earth unknown;

Smiles, that with motion of their own

Do spread, and sink, and rise;

That come and go with endless play,

And ever, as they pass away,

Are hidden in her eyes. (lines 7-12) ${ }^{32}$

The contrasting short lines of the tail-rhyme stanza here give emphasis to a process of secretion: "hidden in her eyes" makes the seeing organ one of concealment rather than perception. It becomes a repository of once openly expressed, outward, smiles that are prevented from entire loss by this internalization. The woman's innocent spiritual self ("unknown" - not in the realm of earthly knowledge) would be lost but is preserved, translated, as a non-communicative trace within the normally most perceptive part of the body. This is elegiac in the sense that the woman is made an embodied archive of her own spiritual being: she remains, then, for the smitten narrator, elusive-he is a follower in her step, not her knower or possessor.

The tail-rhyme stanza performs a similar process of recession and arrest in "Three Years She Grew In Sun and Shower":

"The floating clouds their state shall lend

To her; for her the willow bend;

Nor shall she fail to see

Even in the motions of the storm

A beauty that shall mould her form

By silent sympathy.

The stars of midnight shall be dear

To her; and she shall lean her ear

In many a secret place

30 On Wordsworth's and others' earlier uses of the stanza, see Brennan O'Donnell, "Numerous Verse: A Guide to the Stanzas and Metrical Structures of Wordsworth's Poetry," Studies in Philology, 86 (1989): 1-148. Also, Jerome Mitchell “Wordsworth's Tail Rhyme 'Lucy' Poem,” Studies in Medieval Culture, 4 (1974): 561-8, and Caroline Strong, "History and Relations of the Tail-Rhyme Strophe in Latin, French, and English,” PMLA, 22 (1907): 371-420.

31 On loss in the Lucy poems, see Peter Larkin, Wordsworth and Coleridge: Promising Losses (New York: Palgrave Macmillan, 2012), 93-105.

32 Wordsworth, Poems in Two Volumes, and Other Poems, 1800-1807, ed. Jared R. Curtis (Ithaca and London: Cornell University Press, 1983), 69-70. 
Where rivulets dance their wayward round, And beauty born of murmuring sound

Shall pass into her face.

And vital feelings of delight

Shall rear her form to stately height,

Her virgin bosom swell,

Such thoughts to Lucy I will give

While she and I together live

Here in this happy dell."

Thus Nature spake - The work was done -

How soon my Lucy's race was run!

She died, and left to me

This heath, this calm and quiet scene;

The memory of what has been,

And never more will be. - (lines 19-42) 33

The process of translation is similar: imagery makes Lucy aerial and star-like as it does Fermor. But the 1824 poem will not rest content with "never more will be": its response to the earlier poem is to redirect metamorphosis towards a spiritual presence that the woman's death allows mourners to intimate as an attainable future state. It is an unorthodox, pantheistic spirituality and it is also communal. It shows memory not as the exclusive possession of a single lover, but as a resource established by the poet so that his fellow mourners may project an ended life forward and understand the nature into which that life is dispersed as being proleptic of heaven. Poetry's role, as it takes up the task of elegy, is no longer as in 1800 to dramatize the yearnings, terrors and even fracture of a sole self ("oh! / the difference to me") but to find words in which a public - a circle of friends and, beyond them, the readers - can bear its losses and discover in memory both compensation and expectation. As a result, it may be less intense as a revelation of personal subjectivity, less "lyrical," but is more engaged with the poet's historical mission to articulate, in ceremonial form, the hopes and fears of his community. It fulfils this mission, however, in disturbance-radically reforging the terms in which the community normally expresses its hopes and fears rather than conforming to approved ideology. In this regard, it is worth noting that Wordsworth also commemorated Fermor in a "Cenotaph" (i.e an epitaph for a monument or tomb from which the body of the deceased is absent). This memorial used the same tail-rhyme form as the "Elegiac Stanzas":

33 Lyrical Ballads and Other Poems 1797-1800, ed. James Butler and Karen Green (Ithaca and London: Cornell University Press, 1992), 221-2. 
By vain affections unenthralled, Though resolute when duty called

To meet the world's broad eye, Pure as the holiest cloistered nun That ever feared the tempting sun, Did Fermor live and die.

This Tablet, hallowed by her name,

One heart-relieving tear may claim;

But if the pensive gloom

Of fond regret be still thy choice,

Exalt thy spirit, hear the voice

Of Jesus from her tomb!

\section{"I AM THE WAY, THE TRUTH, AND THE LIFE"}

Here the short lines create the stasis and finality that is appropriate for epitaph. Impersonality, becoming monumentality, is a product of formal control—and it is the authority gained by this control that allows the poet to instruct the reader ("Exalt thy spirit"), confident that he can summon the written words of the Bible as speech-and not just any speech, but the speech of Christ ("hear the voice / Of Jesus"). This is prosopopeia to the power of three: Fermor's absence from her memorial licenses Wordsworth not only, as is normal in epitaphs, to give his writing unearthly power by addressing the reader about the deceased (or in the voice of the deceased) as if from the tombstone, but also to do so in the voice of Jesus, whose absence from his tomb indicated his resurrection-his crossing of the death/ life soul/body boundaries. Fermor's absence-both from her memorial and from the world-is not to be regretted because Jesus shows that absence can represent presence: he is gone in body but renewed as the Word. He is thus a guarantor of Fermor's, and the mourners,' renewal as spirit. More than this, he is a figure for the poet, who can make the absent present again, if not in body then as written words. This is usurpation as piety: summoning the Bible as authority, Wordsworth is both orthodox and heretical, for the final quoted line is at once his own poetic script, the inscription on the stone, and Jesus's words. It is resurrected from the dead letter as the reader deciphers it and articulates it in his head: so, thereby, is Wordsworth, its inscriber. It is the poet's way, truth and life, as well as Jesus's, that is offered as the last (and first) word.

"Cenotaph" suggests that the impersonality that Wordsworth achieved by use of the tail-rhyme stanza aligns his elegiac poems with neo-epitaphs. Both genres are modified in the process: in Wordsworth, they become verbal machines in which poised formality monumentalizes the subject via an association of images. They are not proto-lyrics in the sense that Coleridge's and J. S. Mill's remarks 
suggest: the voice modelled is public and ceremonial rather than personal and inward. Yet they are intensely emotive: mastery of traditional poetic form, rather than self-reflexive apostrophes to nature or to his own imagination (as in The Prelude), allows an intimation of transcendence. Adapting the form and voice of particular past poems, they display Wordsworth's awareness that by relating these scattered predecessors to each other in his own work, he brings past poems into relationship with each other and with the present, creating literary history. This history is doubly a process of refinement: first, the poems in question are linked"elegized" - on the basis that each performs the task of transforming the messiness of the temporal into the purity of the eternal; second, Wordsworth refines the techniques of his predecessors. The new work is a honed, clarified version of the old: literary history is progress rather than repetition or regression-elegization is a quintessence of past writings just as, in the poems, death is a distillation of the to-ings and fro-ings of life. Wordsworth elegizes poetic history and historicizes his elegy in the same gesture. All this, however, is dependent on leaving behind the imbrication of form and subject-matter in particular spatio-temporal contexts: the history created is literary; the poems that Wordsworth adapts no more come trailing clouds of social or political context than does the person whose life his poem commemorates. It's a gendered process: the male poet writing of the dead woman finds a certain language of purification and refinement easier to attain because he is content to leave her details-her deeds-behind (content because he and his culture emphasize women's virtues as exemplified in their bodies and characters [chastity, beauty, charity etc.] over a history of their actions [these being largely restricted to private life]). She becomes an icon-a generic figure-a collection of formal features exquisitely arranged.

If Wordsworth elegized the poems he adapted by the use he made of them to commemorate the lost and the dead, did later poets do something similar to his work? Can we retrieve an elegiac tradition that critical backdating of lyricization has subsumed into the lyrical? While there is insufficient space here for a full discussion, I note that in In Memoriam, A Shropshire Lad, and Poems of 1912-13, what is seen as the hallmark of the lyric_- "feeling confessing itself to itself in moments of solitude"-occurs in the context of mourning death, suggesting that key aspects of the "lyrical" were practised as the elegiac. Tennyson, Housman and Hardy wrote "lyrics" that are considerably more subjective and confessional than Wordsworth's elegy for Fermor but fit Coleridge's description of the elegy as poetry that treats "no subject for itself; but always and exclusively with reference to the poet." They also adapted the techniques that Wordsworth had himself adapted when turning seventeenth-century "metaphysical" poems towards elegy-arguing through an accumulation of metaphoricized images of observed natural objects, and closing each argument at the stanza-end with a final shorter tail-rhyme. Tennyson's famous lines on Hesper-Phosphor argue through images; they also echo particular images that Wordsworth used in elegizing Vesper as evening star and evening prayer: 
Sad Hesper o'er the buried sun

And ready, thou, to die with him, atchest all things ever dim dimmer, and a glory done:

The team is loosen'd from the wain,

The boat is drawn upon the shore;

Thou listenest to the closing door,

And life is darken'd in the brain. (In Memoriam Canto 121) $)^{34}$

Hardy takes the tail-rhyme stanza to a limit-point of terseness in "In Time of the Breaking of Nations:"

Only a man harrowing clods

In a slow silent walk

With an old horse that stumbles and nods

Half asleep as they stalk.

II

Only thin smoke without flame

From the heaps of couch-grass;

Yet this will go onward the same

Though Dynasties pass.

III

Yonder a maid and her wight

Come whispering by:

War's annals will cloud into night

Ere their story die. ${ }^{35}$

Spareness_both verbally and formally-is important here. Each image is both particular and general - an individual sight with time, place and identity left unspecified. The man is an unromanticized rural labourer; he roots in the real world the maid and wight, who could come from any pastoral poem in the English tradition. Reduced to a minimum of words, deprived of main verbs, the images tell of vestigial vitality yet form a list, cumulatively generating an argument by analogy.

34 Tennyson: a Selected Edition, ed. Christopher Ricks, rev. edn. (Abingdon and New York: Routledge, 2014), 331-484.

35 From Moments of Vision, Collected Poems of Thomas Hardy (London: Macmillan, 1930), 511. 
By this means they justify the final assertion that life survives mass death, because it can be told in a form so simple that it seems impossible to reduce it further. Form and voice are vital to the effect: not only does Hardy remain impersonal but he also diminishes line length to achieve a crystalline minimality. Each of the images is divided into two distinct aspects by being articulated across a short, followed by a still shorter line-a variant on the tail-rhyme procedure that Wordsworth had adopted in his elegiac stanzas.

Both Hardy and Tennyson then, develop forms and methods that Wordsworth had himself developed when he turned the songs of Marvell and Smart towards the contemplation of loss. To this extent the rise of lyricization that their work is said to epitomize can also be seen as the persistence of elegization-as a matter of technique as well as mood. What is gained from seeing it in this way is a perspective on poetry's continuing social dimension: in Housman too the revelation of individual inner feeling retains a social function - to explore feelings of loss is to teach others how to mourn. Thus the elegiac is not, as Easthope and Jackson have suggested of the same poetry viewed as "lyric," a poetry that models a relationship between writer/speaker and reader/hearer so decontextualized as to be solipsistic. Forging and reforging a language to speak of death, the elegiac hybrid shapes the writer/reader relationship in interaction with poetry's traditional communal function of commemoration-a function inseparable from its form and style. In effect, the English lyric, seen as a post-Wordsworthian genre, reaches its apotheosis not as an aestheticization of confessional emotion silently transferred from writer to reader, but as a reworking of inherited form for the purpose of contemplating death. 